\title{
Parempi sytyttää kynttilä kuin kirota pimeyttä
}

Juha Suoranta

Paulo Freire - Sorrettujen pedagogi

Into, Helsinki 2019

Voitto Kuosmanen

Daulo Freire (1921-1997) on tunnettu kasvatus- ja yhteiskuntafilosofi. Hänen filosofiansa on kiehtonut vapautumisesta kiinnostuneita ajattelijoita ja toimijoita. Hänen pääteostaan Sorrettujen pedagogiikka on käännetty 20 kielelle, ja sitä on painettu yli miljoona kappaletta. Freiren filosofia on vaikuttanut erityisesti Latinalaisen Amerikan ja Afrikan maissa, joissa on taisteltu sorrosta vapautumisesta. Freiren ajatteluperinne on ollut viime vuosikymmeninä läsnä niin tieteissä, yhteiskunnallisissa liikkeissä kuin taiteissa - kaikkialla, missä ihmisen oma ääni on haluttu esiin edistämään yhteiskunnallista tasa-arvoa ja demokratiaa. Kaikkia Freiren ajattelu ei ole kiehtonut. Vaaralliseksi sen ovat kokeneet tahot, jotka ovat halunneet varmistaa vallitsevan - sortavan - järjestyksen jatkumisen yhteiskunnissa. Jotakin kiinnostavaa miehessä ja hänen filosofiassaan yhä on, koska vuonna 2019, yli kaksi vuosikymmentä hänen kuolemansa jälkeen, Brasilian presidentiksi valittu Jair Bolsonaro on vaatinut koko koulujärjestelmän ja Brasilian puhdistamisesta "Freiren ideologiasta".

Kuka oli Paulo Freire? Kuinka hänestä tuli sorrettujen pedagogi? Miten Freiren yhteiskunnallisesta sorrosta vapautumiseen tähtäävä pedagogiikka sai alkunsa? Miksi Freire luotti sekä Marxiin että Jeesukseen ja ryhtyi kamppailuun yhteiskunnallista fanatismia vastaan? Miksi hän uskoi, että vaikka maailmassa on välillä pimeää, solidaarisuuden valo voittaa pimeyden? Näihin kysymyksiin Juha Suoranta on etsinyt vastauksia uutuuskir- 
jassaan Paulo Freire - Sorrettujen pedagogi. Aiemmin hän on avannut Freiren ajattelua opetustyössään, kriittisen pedagogiikan kirjoituksissaan, julkaisussaan Radikaali kasvatus - kohti kasvatuksen poliittista sosiologiaa (2005) sekä yhdessä Sanna Ryynäsen kanssa teoksessa Taisteleva tutkimus (2014).

Sorrettujen pedagogi -kirjan alussa Suoranta toteaa, että Freireä käsittelevissä "kuvissa" ei näy radikaalia ja vallankumouksellista Freireä. Esillä on enemmän tai vähemmän kesytetty, historiallisista yhteyksistä irti oleva Freire. Suoranta haluaa saada näkyviin, kuinka epäoikeudenmukaisuuden kriitikosta, joka ahkerasti perehtyi erilaisiin aatevirtauksiin, kehkeytyi vallankumouksellinen filosofi ja pedagogi. Suorannan metodi on hermeneuttinen. Hän haluaa tutkia Freiren hengen, ajattelun ja toiminnan kehittymistä ajassa ja paikassa aikakauttaan heijastaen, yhteyksissä vallitseviin sosiaalisiin, kulttuurisiin ja poliittisiin olosuhteisiin. Hän jakaa Freiren kehittymisen vallankumoukselliseksi kahteen ajanjaksoon. Ensimmäisen ajanjakson (1945-1964) Freire toimi Brasiliassa ja toisen maanpakolaisena Chilessä (1964-1969), missä hän kirjoitti pääteoksensa Sorrettujen pedagogiikka (1968).

Brasiliassa elettiin vuosina 1945-1964 demokraattisen kokeilun aikaa. Freire oli opiskellut juristiksi, mutta ammatin rajat tuntuivat ahtailta tiedonhaluiselle miehelle. Ajan ilmapiiri oli suosiollinen Freiren halulle osallistua yhteiskunnan uudistamiseen. Työ sosiaali-, terveys- ja koulutusasioiden kehittämisessä toi hänen tietoisuuteensa Brasilian ongelmat ja kehittämisen haasteet. Työskentely köyhien maatyöläisten kanssa auttoi häntä oivaltamaan syvemmin yhteiskunnan sortavat rakenteet. Freiren elämänkumppanin Elzan merkitys tässä asiassa oli myös suuri. Teos tuo esille Elzan, joka auttoi miestään kuuntelemaan ja avaamaan silmänsä alempien yhteiskuntaluokkien todellisuudelle: Paulo, sinä et ymmärrä heitä. Kuuntele, tuo mies opettaa sinulle yhteiskunnallisen eriarvoisuuden aakkoset.

Voimistuva vasemmistolainen poliittinen ilmapiiri avasi 1960-luvun alussa Freirelle mahdollisuuden toteuttaa luku- ja kirjoitustaitokampanjaa, jossa ihmisten oma kieli, kokemukset ja ajattelutavat olivat oppimisen lähtökohtina. Tulokset olivat hämmästyttäviä. Aikuiset oppivat parhaimmillaan 30-40 tunnin opiskelun jälkeen lukemisen ja kirjoittamisen taidot ja siinä sivussa kriittisen tavan tarkastella vallitsevaa kulttuuria ja yhteiskunnallista järjestystä. Brasilian eliitti tunsi vallitsevan järjestyksen ja oman asemansa uhatuksi. Sotilasvallankaappaus lopetti menestykselliset 
luku- ja kirjoitustaitokampanjat. Freireä, joka tuolloin oli Suorannan mukaan poliittisesti maltillinen sosiaaliliberaali, syytettiin yrityksestä politisoida köyhä väki ja käyttää luku- ja kirjoitustaitokampanjaa kommunististen aatteiden levittämiseen. Todistusaineistoa ei löytynyt. Freire joutui perheineen pakenemaan maasta.

Maanpaossa Chilessä Freire radikalisoitui. Häneen tarttui kumousinto, kirjoittaa Suoranta. Latinalaisessa Amerikassa sorrosta vapautumiseen suuntaavan, vasemmistolaisen ajattelun suosio oli kasvanut. Myös Chilessä puhalsivat tuolloin muutoksille suotuisat tuulet. Vallassa olevat kristillisdemokraatit olivat valmiita maa-, koulutus- ja asuntopoliittisiin uudistuksiin sekä antamaan äänioikeuden naisille, nuorille ja talonpojille. Maanpaossa Freire toteutti luku- ja kirjoitustaitokampanjaansa, keskusteli vasemmistolaisten intellektuellien kanssa ja tutustui kriittisiin ajattelijoihin.

Tutustuttuaan Marxin ajatteluun hän oivalsi, että kasvatus ja koulutus eivät yksin riitä yhteiskunnan uudistamiseen ja sorrosta vapautumiseen. Tarvitaan vanhan järjestyksen kumoaminen. Koska ihmiset luovat omilla teoillaan maailman, he voivat sen myös muuttaa. Freire päätyi siihen ajatukseen, että kasvatuksessa, kuten kaikessa yhteiskunnallisessa toiminnassa, pitää toteutua jatkuvan vallankumouksen idea. Jos maailman muuttamisen tahto katoaa toimijoiden ajatuksista, heidän toiminnastaan tulee vallitsevan uusintamista ja lopulta sortavaa toimintaa. Historia todistaa, että näin on käynyt useimmille vasemmistolaisille ja muille uudistusliikkeille eri puolilla maailmaa.

Kenestä tahansa ei tule sorrettujen pedagogia. Freire olisi, kuten kuka tahansa, voinut valita vallitsevan järjestyksen palvelijan roolin ja tehtävän. Freire valitsi toisin. Suorannan teos tuo esiin ajattelijan, joka oivalsi jo varhain, että ihmisenä olemisen pyrkimys on inhimillistyä. Tässä asiassa häntä opasti lapsuudessa koettu köyhyys sekä kodin katolisesta vapautuksen teologiasta henkivä tasa-arvoa ja ihmisarvoa kunnioittava ilmapiiri. Lapsuuden kokemuksista virinnyt eetos sai hänen sydämensä sykkimään sorrettujen puolella. Suorannan tutkimus tuo esiin Freiren ihmisenä, jolla on ollut herkkä sosiaalinen omatunto ja oikeudentunto, halu ymmärtää ja tietää sekä tahto toimia sen perustalta, mitä on ymmärtänyt. Nuo viritykset veivät Freiren retkille, joilla lopulta kehkeytyi vapautuksen pedagogi.

Freireä ei filosofointi nojatuolista käsin kiinnostanut. Hän etsi ajatteluunsa filosofisia ja teoreettisia aineksia, jotka toimisivat käytännössä. Hä- 
nestä kehkeytyi synkretisti, jolle eurooppalaiset ajatteluperinteet tulivat tutuiksi. Hän perehtyi eksistentialismiin, personalismiin, dialektiikkaan ja moniin muihin ajatussuuntauksiin ja ajattelijoihin. Vapauden kysymys kutsui hänet tutustumaan eksistentialisteihin, kuten Martin Buberiin, Simone de Beauvoiriin, Jean-Paul Sartreen ja Karl Jaspersiin. Tutustuminen Hegelin herran ja rengin dialektiikkaan avasi Freirelle kriittisen tiedostamisen merkityksen sorrosta vapautumisessa. Tutustuminen Marxiin ja myös Frankfurtin koulukunnan ajattelijoihin tekivät hänestä vallankumouksellisen. Marxin tavoin Freire ei halunnut vain selittää maailmaa vaan muuttaa sitä.

Ilman Marxia ja Jeesusta Freirestä ei olisi tullut sorrettujen pedagogia. Freire oivalsi, että Marx ja Jeesus ovat veljeksiä, jotka katselevat samaa maisemaa ja tekevät samansuuntaiset johtopäätökset näkemästään. Suoranta kirjoittaa: "Marxin ja Jeesuksen pelastussuunnitelmissa on paljon samaa. Ihmisen ja yhteiskunnan uudistamiseksi tarvittiin vanhan järjestyksen kumoamista, mikä synnyttäisi uuden maailman ja valtakunnan. Sorrettujen kunniakas tehtävä oli luoda maailma uudeksi liittymällä yhteen." Freiren oivallukset heittävät haasteen kristityille, joita, lukuun ottamatta vapautuksen teologeja, ei ole näihin päiviin asti kovin paljon innostanut eriarvoisen ja sortavan yhteiskunnan ympärikääntäminen.

Kirjaa lukiessa tulee mieleeni, että se, mitä Freire halusi luku- ja kirjoitustaidon oppimisessa tapahtuvan ihmisille, oli tapahtunut hänelle itselleen. Kirjan alkulehdillä sorrettujen pedagogi ajatteli vallankumouksellisesta kasvatuksesta seuraavasti: "Vallankumouksellisessa kasvatuksessa oppijat ohjataan ajattelemaan. Tietoiseksi tuleminen ei ole tyhjä hokema eikä iskulause, vaan se tarkoittaa ihmisenä olemisen radikaalia muotoa. Sillä viitataan ihmiseen, joka ei ainoastaan tiedä vaan joka tietää tietävänsä. Tässä mielessä lukemaan ja kirjoittamaan oppiminen on luovaa toimintaa, johon sisältyy todellisuuden kriittinen ymmärtäminen." Suorannan tutkimus tuo esiin Freiren, joka itse toteutti omassa elämässään vallankumouksellisen itsekasvatusprojektin.

Suoranta toteaa, että Freiren ympärille ei ole muodostunut koulukuntaa. Itseoppinut Freire ei itsekään halunnut perustaa oppia, jota toiset sitten orjallisesti seuraavat. Suorannan mukaan Freire heitti haasteen vapaudesta ja vapautumisesta innoittuneille kasvattajille ja opettajille: sorrosta vapauttamaan ryhtyvän pedagogin on itse löydettävä tapa soveltaa ajattelu- ja toimintatapaansa vallitseviin historiallisiin, kulttuurisiin, sosiaalisiin ja poliittisiin olosuhteisiin. 
Suorannan tutkimus haastoi pohtimaan Freiren ajankohtaisuutta. Joko olisi aika haudata Freiren filosofia? Presidentti Jair Bolsonaron sekä muiden populistien, fanaatikkojen ja uusliberaalien ajattelijoiden mielestä näin pitäisi tehdä. Juuri siksi Freiren ajatuksia ei pidä nyt haudata.

Kun katsoo maailmaa, ihmistä vastaan kohdistuvat kulttuuriset ja yhteiskunnalliset sorron rakenteet ja muodot eivät ole sieltä minnekään kadonneet: Niin sanotuissa kehittyneissä maissa luku- ja kirjoitustaidottomuus sekä luetun ymmärtämisen vaikeudet yleistyvät. Yhdysvalloissa on kymmeniä miljoonia käytännössä luku- ja kirjoitustaidottomia ihmisiä. Suomessakin samaan ilmiöön on havahduttu. Pyrkimykset vahvistaa moniäänistä ja monikulttuurista maailmaa saavat vastaansa totalitaarisia ja väkivaltaisia hankkeita. Globaali kapitalismi ja sen ideologia, uusliberalismi, koettaa parhaansa mukaan tehdä maailman ihmisistä hyödyllisiä kuluttajakansalaisia, jotka eivät olisi kiinnostuneita tulevaisuudesta, saati oman elämän mielekkyyden ja merkityksellisyyden etsinnästä. Näinä aikoina ihmiset innostuvat enemmän kuin vuosikymmeniin nationalistisista, fasistisista ja muista liikkeistä, jotka suhtautuvat vihamielisesti ihmisryhmiin, jotka näyttävät toisenlaisilta ja joilla on erilaisia ajatuksia ja uskomuksia kuin itsellä. Barbaariset viritykset, pois sulkevan yhteiskunnan ideat, ovat vahvistuneet kansallisvaltioiden rajat - jo ajat sitten - ylittäneessä maailmankansalaisen identiteetin rakentajia kaipaavassa maailmassa. Viheliäiseksi muuttuneessa maailmassa sorrosta vapautumisen ja vallankumouksen haaste on tullut entistä ajankohtaisemmaksi.

Suorannan teos haastaa lukijan pohtimaan, kuuluuko tulevaisuus ihmisille vai barbaareille ja maailmanvalloille. Freiren filosofian ytimessä on ajatus, että tulevaisuus on aina avoin. Siksi on hyvä pohtia, millainen tulevaisuus on tavoittelemisen arvoinen. Maailma on siirtymässä älykkään teknologian, robotiikan ja automaation aikakauteen. Yhteiskuntien taloudellisteknisen perustan kehitys on antamassa tilaa toivon heräämiseen, mahdollisuuteen vahvistaa kulttuuria ja yhteiskuntaa, jossa ihmiset voisivat käyttää ääntään ja toteuttaa parasta itseään. Paradoksaalisesti uuden aikakauden porstuassa olevassa maailmassa ihmisille toivoa tarjoavat uusliberalistit, fanaatikot ja populistit - kaiken maailman ajattelun ja toiminnan miehittäjät.

Vallankumous hipsuttaa sukkasillaan, kunnes se alkaa muuttua koko ajan äänekkäämmäksi. Vanhan maailman nurinkääntämiseen on syntynyt poliittisia ja sosiaalisia liikkeitä, joista ilmastonmuutosliike lienee merkittävin. Kirjan kirjoittaja, sorrettujen pedagogi itsekin, kehottaa freireläises- 
sä huoneentaulussaan rakentamaan vaihtoehtoisia olemisen ja elämisen tapoja, kannustaa menemään mukaan liikkeisiin, joissa puolustetaan demokratiaa ja ihmisoikeuksia ja taistellaan yhteiskunnan autoritaarisuutta vastaan. Osallistuminen ja aktiivinen toiminta auttaa kehittämään kriittistä tietoisuutta. "Sorretuista tulee kapitalismin haudankaivajia, jotka yhdistyvät tuhoavan yhteiskuntajärjestelmän kumoavaksi joukkovoimaksi."

Kirjaa lukiessa ajattelen ihmisiä, joille kasvattajina ja opettajina riittää lasten ja nuorten sosiaalistaminen vallitsevaan yhteiskuntaan sekä aikuisten valmentaminen tuottaviksi kansalaisiksi. Sorrettujen pedagogi -teos sai pohtimaan, kuinka ihmistä oppimaan ja kasvamaan saattajiin ja kehen tahansa syttyisi rakkauden ja oikeudenmukaisuuden palo, joka vauhdittaisi muutosta kohti sorrosta vapaata ja oikeudenmukaista maailmaa? Freiressä tuo palo roihusi: "I am intellectual who is not afraid to be romantic; I love people and love the world. And it is because I love people and I love the world that I fight for social justice implanted before charity." 